Article

\title{
Identification of Plant DNA in Adults of the Phytoplasma Vector Cacopsylla picta Helps Understanding Its Feeding Behavior
}

\author{
Dana Barthel ${ }^{1, *}$, Hannes Schuler ${ }^{2,3}{ }^{\mathbb{C}}$, Jonas Galli ${ }^{4}$, Luigimaria Borruso ${ }^{2}{ }^{(D}$, Jacob Geier ${ }^{5}$, \\ Katrin Heer ${ }^{6}\left(\mathbb{D}\right.$, Daniel Burckhardt ${ }^{7}$ (D) and Katrin Janik ${ }^{1, *(\mathbb{D})}$ \\ 1 Laimburg Research Centre, Laimburg 6, Pfatten (Vadena), IT-39040 Auer (Ora), Italy \\ 2 Faculty of Science and Technology, Free University of Bozen-Bolzano, IT-39100 Bozen (Bolzano), Italy; \\ hannes.schuler@unibz.it (H.S.); luigimaria.borruso@unibz.it (L.B.) \\ 3 Competence Centre Plant Health, Free University of Bozen-Bolzano, IT-39100 Bozen (Bolzano), Italy \\ 4 Department of Forest and Soil Sciences, BOKU, University of Natural Resources and Life Sciences Vienna, \\ A-1190 Vienna, Austria; jonasgalli95@gmail.com \\ 5 Department of Botany, Leopold-Franzens-Universität Innsbruck, Sternwartestraße 15, \\ A-6020 Innsbruck, Austria; jacob.geier@laimburg.it \\ 6 Faculty of Biology-Conservation Biology, Philipps Universität Marburg, Karl-von-Frisch-Straße 8, \\ D-35043 Marburg, Germany; katrin.heer@uni-marburg.de \\ 7 Naturhistorisches Museum, Augustinergasse 2, CH-4001 Basel, Switzerland; Daniel.Burckhardt@bs.ch \\ * Correspondence: dana.barthel@laimburg.it (D.B.); katrin.janik@laimburg.it (K.J.)
}

Received: 10 November 2020; Accepted: 24 November 2020; Published: 26 November 2020

Simple Summary: Cacopsylla picta is an insect vector of apple proliferation phytoplasma, the causative bacterial agent of apple proliferation disease. In this study, we provide an answer to the open question of whether adult Cacopsylla picta feed from other plants than their known host, the apple plant. We collected Cacopsylla picta specimens from apple trees and analyzed the composition of plant DNA ingested by these insects. By applying a state-of-the art sequencing approach, we show, for the first time, that Cacopsylla picta feeds from a wide range of woody and herbaceous plant species. Our results are important for a better understanding of the biology and feeding behavior of Cacopsylla picta. Since this insect is an efficient vector of apple proliferation phytoplasma, our results are also important to define potential reservoir plants that might be involved in the transmissive cycle of this pathogen. This study thus provides important data of practical relevance.

Abstract: Apple proliferation is an economically important disease and a threat for commercial apple cultivation. The causative pathogen, the bacterium 'Candidatus Phytoplasma mali', is mainly transmitted by Cacopsylla picta, a phloem-feeding insect that develops on the apple tree (Malus spp.). To investigate the feeding behavior of adults of the phytoplasma vector Cacopsylla picta in more detail, we used deep sequencing technology to identify plant-specific DNA ingested by the insect. Adult psyllids were collected in different apple orchards in the Trentino-South Tyrol region of northern Italy. DNA from the whole body of the insect was extracted and analyzed for the presence of plant DNA by performing PCR with two plant-specific primers that target the chloroplast regions trnH-psbA and $r b c L a$. DNA from 23 plant genera $(\operatorname{trnH})$ and four plant families $(r b c L a)$ of woody and herbaceous plant taxa was detected. Up to six and three plant genera and families, respectively, could be determined in single specimens. The results of this study contribute to a better understanding of the feeding behavior of adult Cacopsylla picta.

Keywords: apple proliferation; feeding behavior; food plants; phloem feeding; Psylloidea; $r b c L a$; sequencing; $\operatorname{trn} H$ 


\section{Introduction}

Apple proliferation (AP) is an economically important disease in commercial apple cultivation and is caused by the cell wall-less bacterium 'Candidatus Phytoplasma mali' [1]. Formation of witches' brooms and enlarged, dentate stipules are specific symptoms that unambiguously characterize this disease [2,3]. Infected plants produce small, tasteless and colorless fruits that are not marketable [3]. Since there is no curative treatment for the infected trees, they have to be uprooted to prevent further spread of the pathogen. The financial loss caused by the quality loss and financial expenditure of tree removal was about EUR 100 million in Italy in 2001 and about EUR 50 million in the province of South Tyrol in 2006 and 2013 [4,5]. AP is a constant threat in apple-growing regions. The pathogen is transmitted by the phloem-feeding insects Cacopsylla picta (Foerster 1848) (synonym Psylla costalis; Flor 1861) (Hemiptera: Sternorrhyncha: Psyllidae), C. melanoneura (Foerster 1848) and Fieberiella florii (Stål 1864) (Hemiptera: Auchenorrhyncha: Cicadellidae) [6-11]. 'Ca. P. mali' infects Malus spp., but the pathogen could be also detected in wild and ornamental plants (reviewed in Janik et al.; [5]). In plants, the bacterium colonizes the phloem, and C. picta can, thus, acquire the pathogen during feeding on an infected plant. In a competent vector, the bacterium replicates and migrates to the salivary glands and is released to the insect's saliva. Due to saliva release during psyllid feeding activity, the pathogen can be further transmitted to new plants [12]. As C. picta can transmit ' $\mathrm{Ca}$. P. mali' transovarially to its progeny, a single mother individual can produce hundreds of infected descendants and even a small C. picta population can lead to severe AP outbreaks [13]. C. picta is considered the main vector of the AP-inducing pathogen [14-16].

Cacopsylla picta is univoltine, i.e., it reproduces once a year. The insect is considered monophagous, meaning that the immatures feed and develop exclusively on one host plant taxon. The host plant taxon on which C. picta immatures feed and develop is Malus spp. [17,18]. In northern Italy, C. picta's reproduction takes place from mid-March until the beginning of August $[19,20]$. During this period, the overwintered adults - the so-called remigrants - of C. picta can be detected in apple orchards until the beginning of June, while the young adults of the new generation-the so-called emigrants-occur from the end of June until the beginning of August [19,20]. During the rest of the year, adults of C. picta dwell on shelter plants, mostly conifers at higher elevations [21]. Immature psyllids are generally restricted to one or several closely related plant species on which they can complete their development. The more mobile adults are often found on various plants on which they presumably feed (= food plants) or overwinter (= shelter plants) [22]. To overcome long distances between host and shelter plants, it is assumed that the insects use convection winds and are passively dispersed by aerial currents [21]. In this manner, psyllids can be transferred by up to as much as $27 \mathrm{~km} \mathrm{[23].}$ While the host plant of C. picta is known, it has been suggested, but not proven, that adult psyllids also feed on other plant taxa [17]. Detailed literature about the feeding behavior of adult C. picta is missing. Only observations regarding the presence of adult $C$. picta on diverse plant species have been reported so far $[17,18,24]$, but it has not been proven that the psyllids feed on these plants.

Psyllids subsist on nutrients, such as minerals, amino acids and sugars, which are the most abundant components of phloem sap $[25,26]$. With their two mandibular and two maxillary stylets, the insects penetrate the plant tissue to reach the phloem sap in the sieve tubes [27-30]. Some plant species prevent insect feeding by applying diverse defense strategies, such as the release of inhibitory or toxic compounds [31] or the occlusion or constriction of sieve pores with callose or phloem proteins [32-35]. Some plants possess a thick-walled sclerenchyma around the phloem which functions as a protective layer against insect feeding [30,36]. Due to successful defense strategies of the plant, psyllids may probe (= stylet penetration) without actually being able to feed on the plant. Plants which do not serve as feeding plants are called casual plants [22]. Even though insertion of the stylet is a time-consuming process for the insect and can take longer than the actual feeding itself $[27,28]$, probing is indispensable for the psyllid to identify its host plant [37,38].

To explore the diet composition of herbivorous insects, different methods have been established. Field observations are time consuming and often error-prone, mainly because this method does 
not allow the determination of whether the plant from which the insect was collected was a casual, feeding or a shelter plant [39]. For plant-chewing insects, a microscopical gut content analysis can give unambiguous insights into feeding behavior. This analysis allows to determine post-prandial residues of plants based on plant morphological characteristics [40,41]. However, since psyllids only ingest phloem sap, no morphologically determinable plant structures are available for a gut content analysis. Detection and identification of plant species-specific DNA regions in the insect does not require morphological plant identification $[39,42]$ and this molecular identification has just recently been shown to be an appropriate method to detect plant DNA in phloem-feeding insects $[43,44]$. Even though phloem cells lack the capacity to synthesize nucleic acids [31], the phloem sap presumably contains plant DNA, e.g., deriving from cellular debris of the phloem tissue used for sieve pore sealing [45]. Phloem companion and mesophyll cells contain chloroplasts and, thus, it can be assumed that chloroplast-derived DNA is also present in the phloem sap [46]. Furthermore, during the stylet penetration process, plant cells are taken up by the insect as well [43]. However, identification of plant DNA in the phloem-feeding insect does not indicate if the insect fed or only probed the plant tissue, or in other words, if the plant DNA derives from a feeding or a casual plant [22].

Knowledge about the dietary composition of phytoplasma vectors is important to determine the range of plants approached by the insect by feeding or probing [12]. An improved understanding of the feeding habits of C. picta and its dispersal provides the basis for the identification of so-far unknown reservoir plants involved in phytoplasma transmission. We applied highly sensitive deep sequencing of chloroplast amplicons to detect plant DNA in whole-body extracts from adult C. picta and gained insights into the feeding behavior of this important phytoplasma vector.

\section{Materials and Methods}

\subsection{Insect Sampling and Morphological and Molecular Species Identification}

From 2012 to 2016, ninety-five adult Cacopsylla picta individuals were collected directly from apple trees. Insects were captured with a conical tunnel-like beat tray connected to a collection vessel or with yellow sticky traps that were placed on apple trees. Sampling was carried out in 14 different apple orchards in the Trentino-South Tyrol (Trentino-Alto Adige) region of northern Italy (Table 1). Dietary composition of the insects before the catch was unknown. Remigrant specimens were collected in March, April and May from all 14 orchards; emigrant specimens were collected in June and July in one orchard (Mais). The captured insects were morphologically determined [18]. DNA of each single individual was extracted using the DNeasy ${ }^{\circledR}$ Blood and Tissue Kit (Qiagen, Hilden, Germany) according to the manufacturer's instruction. DNA was eluted with $100 \mu \mathrm{L}$ Tris-EDTA elution buffer (Tris-Cl 10 mM; EDTA 0.5 mM; pH 9.0) (AppliChem GmbH, Darmstadt, Germany). Species confirmation was performed using restriction fragment length polymorphism according to Oettl and Schlink [47]. Briefly, PCR was performed in a final volume of $20 \mu \mathrm{L}$ containing $1 \times$ Colorless GoTaq ${ }^{\circledR}$ Buffer, $0.2 \mathrm{mM}$ dNTPs, $0.7 \mathrm{mM}$ of each primer and $0.02 \mathrm{U} \mathrm{GoTaq}^{\circledR}$ DNA polymerase (Promega, Madison, USA) under the following conditions: 2 min at $95{ }^{\circ} \mathrm{C} ; 45$ cycles at $95{ }^{\circ} \mathrm{C}$ for $30 \mathrm{~s}, 46{ }^{\circ} \mathrm{C}$ for $30 \mathrm{~s}$ and $72{ }^{\circ} \mathrm{C}$ for $1 \mathrm{~min}$; and $5 \mathrm{~min}$ at $72^{\circ} \mathrm{C}$. Restriction was performed with $10 \mu \mathrm{L}$ of the amplicon and $0.5 \mathrm{U}$ Taq $\alpha$ I restriction enzyme in $1 \times \mathrm{CutSmart}^{\circledR}$ (New England Biolabs Inc., Ipswich, USA) buffer at $65^{\circ} \mathrm{C}$ for $4 \mathrm{~h}$. DNA fragments were separated using 2.0\% MetaPhor ${ }^{\mathrm{TM}}$ agarose (Lonza, Basel, Switzerland) gels and stained with ethidium bromide. Only 'C $a$. P. mali' non-infected C. picta specimens were used in this study. The infection status was determined as described in Mittelberger and co-authors [13]. 
Table 1. The sampling locations of 95 C. picta remigrants (Remi) and emigrants (Emi) from Trentino (TR) and South Tyrol (ST); $n=$ number of specimens (in brackets, the number of specimens that were used for the subsequent sequence analysis. Three insects had to be removed from the sample set because no evaluable sequencing results could be obtained from these specimens); Method = sample type which was either beat tray (Beat) or yellow sticky traps (Trap); Date = collection date; Status = migratory status.

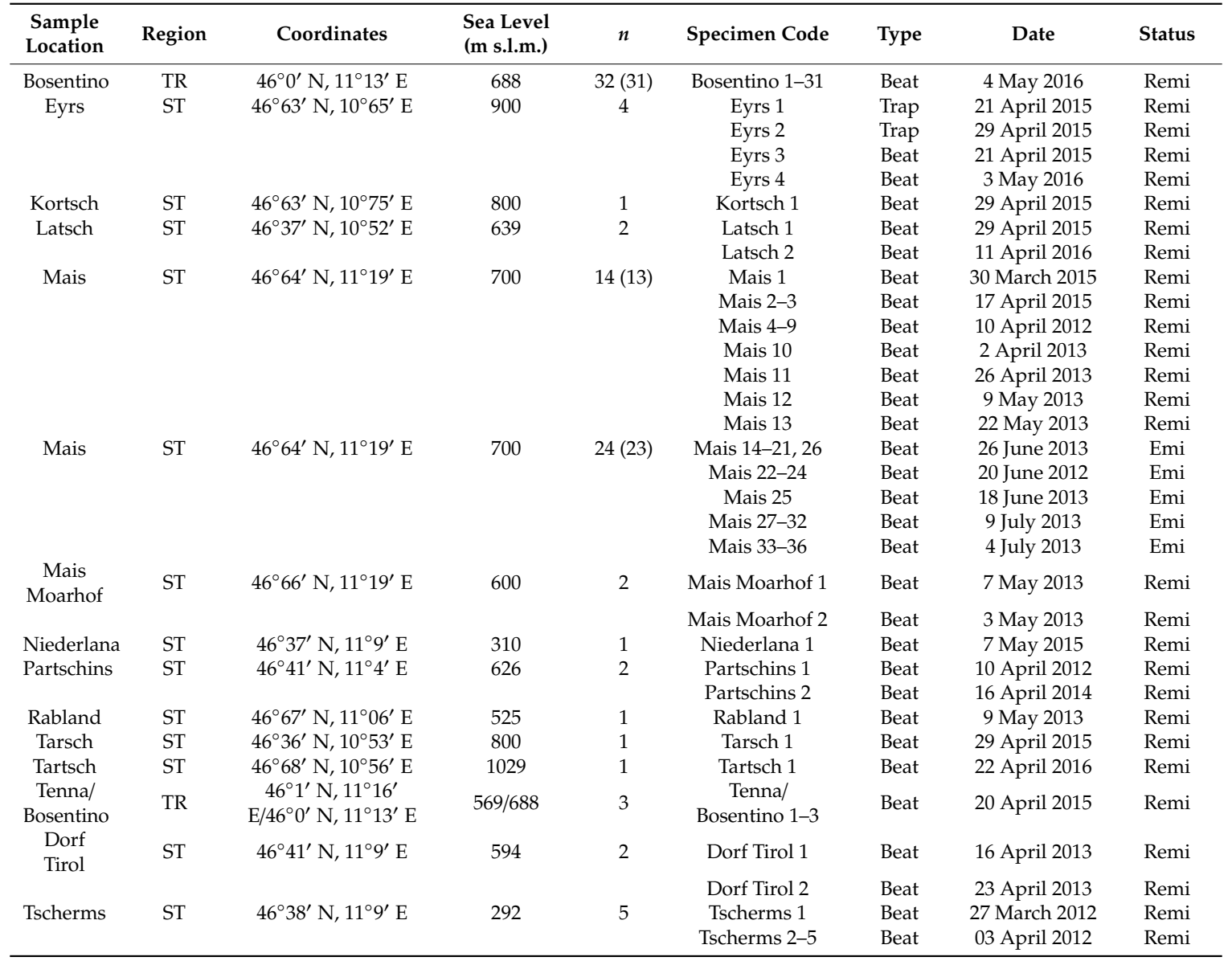

\subsection{Molecular Analysis and Deep Sequencing}

Plant DNA was amplified using the primer pairs psbA-F and trnH-R $[48,49]$ as well as rbcLa-F and rbcLa-R [50,51]. Reaction mixtures of $10 \mu \mathrm{L}$ contained $1 \mu \mathrm{L}$ of template DNA (ca. $50 \mathrm{ng}$ ), $2 \mu \mathrm{L}$ of $5 \times$ MyTaq $^{\mathrm{TM}}$ Buffer, $0.75 \mu \mathrm{L}$ of each primer $(10 \mu \mathrm{M}), 1 \mu \mathrm{L}$ of BioStab PCR optimizer (II) (Merck, Darmstadt, Germany), $0.15 \mu \mathrm{L}$ of MyTaq ${ }^{\mathrm{TM}}$ Polymerase (5 U/ $\mu \mathrm{l}$ ) (Meridian Bioscience, London, UK) and $4.35 \mu \mathrm{L}$ molecular grade water. PCR and amplicon sequencing were conducted at LGC Genomics $\mathrm{GmbH}$ (Berlin, Germany). The PCR was performed as follows: Initial denaturation for 2 min at $95^{\circ} \mathrm{C}$ followed by 35 cycles of $15 \mathrm{~s}$ denaturation at $96{ }^{\circ} \mathrm{C}, 30 \mathrm{~s}$ annealing at $58^{\circ} \mathrm{C}$ and 90 s extension at $68{ }^{\circ} \mathrm{C}$; final elongation was performed for $1 \mathrm{~min}$ at $72{ }^{\circ} \mathrm{C}$. Illumina sequencing adapters were attached to the purified PCR products. An extended sequence read length of up to $2 \times 300$ base pairs (bp) obtaining paired-end sequencing was performed on an Illumina ${ }^{\circledR}$ MiSeq $^{\circledR}$ lane (Illumina, Inc., San Diego, CA, USA).

\subsection{Data Analysis}

Amplicon sizes were unexpectedly long for some plant species and forward and reverse sequence reads could not be unambiguously assembled. Thus, for the data analysis, only the forward sequence reads were used. A quality control of the raw sequence reads was done in $\mathrm{R}$ with package DADA2 [52]; sequence reads shorter than 200 bp or with a Phred score of less than 2 were discarded. The operational 
taxonomic unit (OTU) assignment was performed with DADA2 and a further clustering of the OTU sequences was performed with the tool cd-hit with a sequence identity of $99 \%$. The OTU sequence with the most reads was taken as the reference sequence for each cluster. In order to combine the clustering results with the read counts, the data were read in Eclipse using Java and the read counts were summed up for every cluster. Clusters with a minimum of 100 reads were retained and all others discarded. The taxonomical identification was done with an open blast on the National Center for Biotechnology Information database (NCBI) (Bethesda, MD, USA), in which each OTU was individually matched against the complete nucleotide database.

Only BLAST hits with a query cover of at least $99 \%$ were considered to determ OTUs. The OTUs generated with the $\operatorname{trnH}$ locus sequences allowed an assignment up to the taxonomic genus-level, and the results of the rbcLa locus sequencing, up to the taxonomic family-level. OTUs of the same genus $(\operatorname{trn} H)$ or of the same family $(r b c L a)$ were combined. To verify the validity of the OTUs, the taxa were matched to a list of plants naturally occurring in the study region [53,54]. Insects from which no reads passed the sequence quality filtering were excluded.

For both loci, a Mann-Whitney U test was performed to compare the numbers of reads and the number of different plant taxa detected in specimens collected with the beat tray or the sticky traps. All analyses were carried out in the R statistical software (v. 3.1.3) (R studio, Boston, MA, USA).

\subsection{Longevity under Starvation}

Since a reference value for the longevity of $C$. picta under starvation was missing, a survival experiment was carried out. Fifteen emigrants of $C$. picta which derived from a rearing experiment were transferred to an empty 50-mL polypropylene test tube and kept without a food source. A control set built of another fifteen emigrants of C. picta was transferred to another test tube that was put over a branch of a potted spruce and was tightly closed with gauze. All insects were kept in a rearing chamber with $75 \%$ relative humidity, $21^{\circ} \mathrm{C}$ and a day length of $19 \mathrm{~h}$. The number of alive or dead insects was counted every day. The experiment ended after 10 days.

\subsection{Pollen Staining}

As deep sequencing approaches are sensitive to contamination, we investigated the effect of airborne pollen contamination in five C. picta specimens, which were caught with a beating tray in the sampling location Tenna/Bosentino in May 2015. The insects were examined with a light microscope. The staining procedure was performed under a laminar flow to prevent contamination by airborne pollen. The insect was placed on a microscope slide and covered with a few drops of soapsuds (ca. $10 \mathrm{~mL}$ water with 3 drops of curd soap). By carefully shaking the insect on the slide, the hydrophobic pollen grains were detached from the insect's body and dispersed in the soapsuds. The sample was air-dried until the soapsuds were completely evaporated. The sample was then covered with a drop of the dye/embedding solution (containing $0.5 \mathrm{~mL}$ fuchsin-ethanol solution $(0.2 \%), 15 \mathrm{~g}$ polyvinyl alcohol (embedding agent, fully hydrolyzed) and $50 \mathrm{~mL}$ glycerin in $150 \mathrm{~mL}$ water) and covered with a cover slip. The sample was incubated for $24 \mathrm{~h}$ at $22{ }^{\circ} \mathrm{C}$ (room temperature). All pollen grains dispersed in the detergent and attached to the insect's body were counted.

\section{Results}

After a stringent quality control, 393,442 (trnH) and 91,806 (rbcLa) sequence reads were analyzed. On average, 4141 and 144 sequence reads per insect were recorded $(n=92)$ for $\operatorname{trnH}$ and $r b c L a$, respectively (Table A1). One remigrant from Bosentino and one from Mais and one emigrant from Mais were excluded because no plant DNA could be detected using the trnH or the $r b c L a$ primers. Sequencing of the $r b c L a$ amplicon revealed five OTUs that could not be unambiguously assigned to a particular genus but only to a plant family. Considering only plants that naturally occur in the study region, the sequence of the OTU that was assigned to Rosaceae might derive from the genera Malus, Pyrus, Sorbus, Crataegus or Amelanchier. The rbcLa sequences of these five genera are indistinguishable 
and were, thus, designated the Rosaceae OTU. In 75\% of the C. picta individuals, Rosaceae-specific $r b c L a$ sequences were found. Three other OTUs were identified. One OTU could be assigned to the genera Pinus or Picea of the Pinaceae family and another OTU was ambiguously assigned to Cedrus or Larix of the Pinaceae family. Thus, these two OTUs were allocated to the Pinaceae family. Pinaceae DNA was verified in almost every fifth C. picta. DNA of Betulaceae, which indistinguishably match to Betula, Ostrya or Carpinus, was detected in $13 \%$ of the C. picta individuals. Sequences from Fagaceae could derive from Quercus or Castanea and were found in 10\% of the specimens (Table 2 and Figure 1). Taken together, $r b c L a$ sequence assignment allowed to identify DNA derived from four families of woody plants in C. picta (Table 2 and Figure 1).

The sequence analysis of the $t r n H$ amplicon allowed a taxonomic determination up to the genus level, taking into account only plants that naturally occur in the study region. In total, DNA of 23 plant genera comprising 12 woody and 11 herbaceous plant taxa was identified (Table 2 and Figure 1). Specific trnH sequences from Malus were detected in $87 \%$ of the specimens. In about every fifth insect, Fraxinus (Oleaceae)-specific trnH DNA was found. Rumex (Polygonaceae) were found in $16 \%$ of the specimens. DNA from Salix (Salicaceae), Juglans (Juglandaceae) and Betula (Betulaceae) was detected in $11 \%$ and $10 \%$ of the insects, respectively. Pinus- and Picea (both Pinaceae)-specific DNA was found in $7 \%$ of the analyzed C. picta individuals. DNA deriving from cultivated plants, e.g., Cucurbita, Cucumis (both Cucurbitaceae) and Vitis (Vitaceae), was verified in 5\% or less of the specimens. The genera Daucus (Apiaceae), Taraxacum and Lactuca (both Asteraceae), Humulus (Cannabaceae), Juniperus (Cupressaceae), Populus (Salicaceae), Ulmus (Ulmaceae), Urtica (Urticaceae) and Schistidium (Grimmiaceae) were identified in $\leq 5 \%$ of the $C$. picta individuals (Table 2 and Figure 1 ).

The mean number of sequence reads per insect and taxa was less than 100 for the rbcLa locus, while the mean number of reads per taxa varied between 3842 (Malus) and 26 (Quercus) counts for the trnH locus (Table 2, Tables S1 and S2). The number of reads (both loci) from insects that were collected with the beating tray did not significantly differ from those that were collected with sticky traps (Figure A2a).

On average, one plant family and two genera were identified per insect and a maximum of three plant families and six genera in a single individual could be identified (Figure 1). Regardless of the analyzed locus, we could not observe differences regarding the number of different plant taxa in specimens collected with the beat tray or sticky traps (Figure A2b). Most C. picta individuals, i.e., 90\%, were positive for Rosaceae ( $r b c L a)$ or Malus $(\operatorname{trnH})$ at $72 \%$ for both (Figure 1). Figure 2 bundles the information from Figure 1 regarding the presence of Rosaceae, Pinaceae, Betulaceae and Fagaceae DNA in insects from different sampling sites. DNA from Betulaceae was detected in $32 \%$ of the insects from Bosentino, $3 \%$ of the insects from Mais and $28 \%$ of the specimens from other orchards (Figure 2). DNA from Fagaceae was found in 10\% of the individuals from Bosentino, 17\% of the C. picta individuals from Mais and 14\% of those from other orchards (Figure 2). Pinaceae DNA was found in $16 \%$ of individuals from Bosentino, 31\% of those from Mais and 14\% of those from other orchards (Figures 1 and 2). In Mais, remigrants and emigrants were sampled and 69\% of the remigrants of C. picta carried DNA from taxa other than Rosaceae or Pinaceae. DNA from these two families was detected in only $43 \%$ of the emigrants (Figures 1 and 2 ).

In the test tubes without a food source, all emigrants of C. picta died within four days (Figure A1) and the mean longevity under starvation was $1.6 \mathrm{~d}$. All specimens that had the possibility to feed on spruce survived for the entire experiment duration of 10 days.

Pollen was found in very low numbers on the insects with a maximum of four pollen grains per specimen (Table A1, Figure A2a,b). 
Table 2. Plant genera and families detected in C. picta with $\operatorname{trnH}$ and $r b c L a ; n=$ number of specimens with the determined taxa; $(\%)=$ percentage of specimens with determined taxa; $n$ reads = number of total sequence reads in order of size; mean $\pm \mathrm{SD}=$ average number of sequence reads per insect \pm standard deviation.

\begin{tabular}{cccccccc}
\hline Order & Family & Genus & $\boldsymbol{n}$ & $\mathbf{( \% )}$ & $\boldsymbol{n}$ Reads & Mean \pm SD & Locus \\
\hline Rosales & Rosaceae & - & 69 & 75 & 4506 & $65 \pm 18$ & rbcLa \\
Rosales & Rosaceae & Malus & 80 & 87 & 307,347 & $3842 \pm 1022$ & trnH \\
Rosales & Ulmaceae & Ulmus & 4 & 4 & 1801 & $450 \pm 419$ & trnH \\
Rosales & Cannabaceae & Humulus & 1 & 1 & 159 & 159 & trnH \\
Rosales & Urticaceae & Urtica & 1 & 1 & 1794 & 1794 & trnH \\
Coniferales & Pinaceae & - & 17 & 18 & 884 & $52 \pm 17$ & rbcLa \\
Coniferales & Pinaceae & Picea & 6 & 7 & 727 & $121 \pm 61$ & trnH \\
Coniferales & Pinaceae & Pinus & 6 & 7 & 375 & $62 \pm 28$ & trnH \\
Coniferales & Pinaceae & Cedrus & 5 & 5 & 6189 & $1238 \pm 807$ & trnH \\
Coniferales & Cupressaceae & Juniperus & 1 & 1 & 111 & 111 & trnH \\
Fagales & Betulaceae & - & 12 & 13 & 134 & $11 \pm 2$ & rbcLa \\
Fagales & Betulaceae & Betula & 9 & 10 & 706 & $78 \pm 23$ & trnH \\
Fagales & Fagaceae & - & 9 & 10 & 172 & $19 \pm 5$ & rbcLa \\
Fagales & Fagaceae & Quercus & 6 & 7 & 156 & $26 \pm 11$ & trnH \\
Fagales & Fagaceae & Fagus & 1 & 1 & 274 & 274 & trnH \\
Fagales & Juglandaceae & Juglans & 10 & 11 & 12,472 & $1247 \pm 864$ & trnH \\
Lamiales & Oleaceae & Fraxinus & 19 & 21 & 1983 & $104 \pm 36$ & trnH \\
Caryophyllales & Polygonaceae & Rumex & 15 & 16 & 5946 & $396 \pm 242$ & trnH \\
Malpighiales & Salicaceae & Salix & 10 & 11 & 4759 & $476 \pm 273$ & trnH \\
Malpighiales & Salicaceae & Populus & 4 & 4 & 767 & $192 \pm 96$ & trnH \\
Cucurbitales & Cucurbitaceae & Cucurbita & 5 & 5 & 965 & $193 \pm 88$ & trnH \\
Cucurbitales & Cucurbitaceae & Cucumis & 3 & 3 & 415 & $138 \pm 115$ & trnH \\
Asterales & Asteraceae & Taraxacum & 4 & 4 & 325 & $81 \pm 20$ & trnH \\
Asterales & Asteraceae & Lactuca & 2 & 2 & 117 & $58 \pm 19$ & trnH \\
Apiales & Apiaceae & Daucus & 2 & 2 & 1986 & $993 \pm 507$ & trnH \\
Grimmiales & Grimmiaceae & Schistidium & 1 & 1 & 725 & 725 & trnH \\
Vitales & Vitaceae & Vitis & 1 & 1 & 153 & 153 & trnH \\
\hline
\end{tabular}




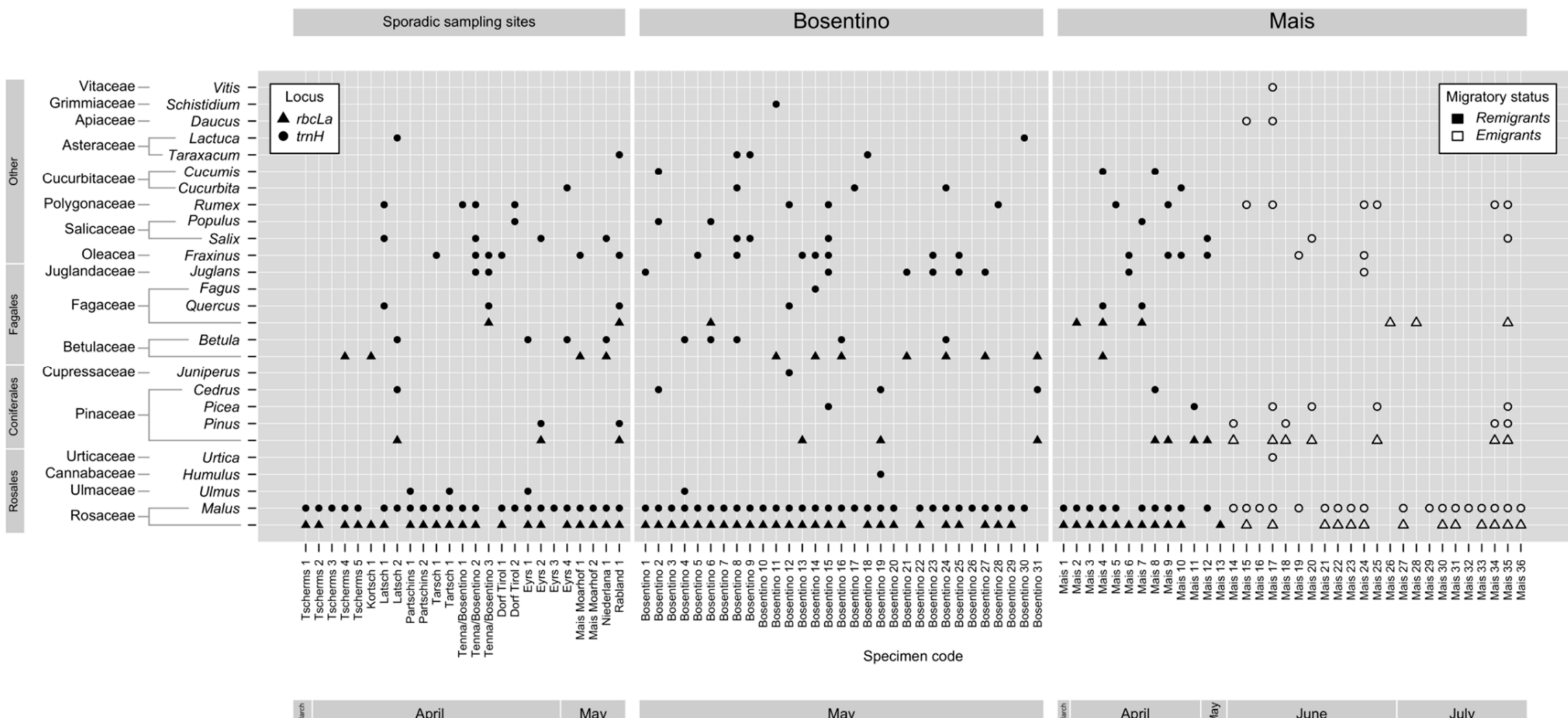

Figure 1. Dietary composition for each C. picta specimen. A total of 95 C. picta individuals were sequenced. In three of these specimens, no plant DNA was found and they were excluded from further analysis. The 92 individuals in which plant DNA was detectable are shown in the graph. The graph is divided into three sections regarding the main sample sites "Bosentino" and "Mais" and "sporadic sampling sites". Remigrants are represented by black symbols and emigrants by white symbols. Triangles (p) and circles (l) indicate sequencing results generated with the $r b c L a$ - or $t r n H$-specific primers, respectively. Quantitative information for every specimen can be found in supplementary Tables S1 and S2. 


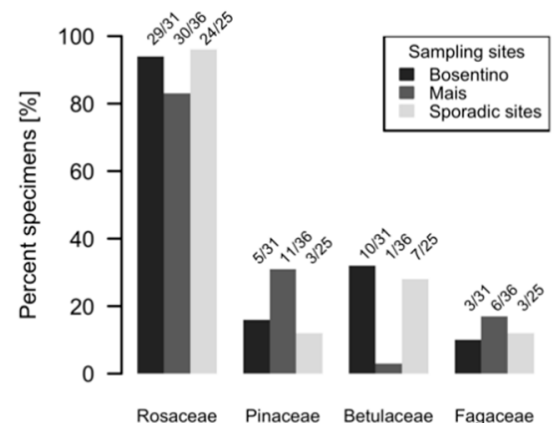

(a)

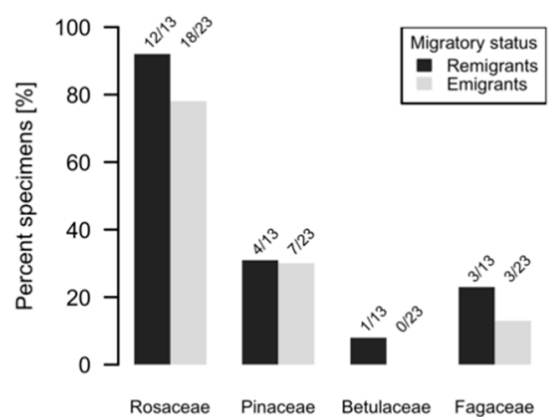

(b)

Figure 2. Detection of selected plant families ( $\operatorname{trnH}$ and $r b c L a)(a)$ in insects deriving from different sampling locations and (b) in remigrants and emigrants deriving from Mais.

\section{Discussion}

The host plant of C. picta is known and it has been suggested [17], but not proven, that adult psyllids also feed on other plant taxa. C. picta can survive for up to four days without food (Figure A2), but the insect lives for only four or five months a year on its host $[19,20]$. This leads to the conclusion that $C$. picta must feed from plants other than Malus. Detailed literature about the feeding behavior of adult $C$. picta is missing. Observations regarding the presence of adult C. picta on diverse plant species have been reported $[17,18,24]$, but it remains unclear if the insects feed on these plants. Therefore, we applied an amplicon deep sequencing approach to identify plant DNA in adult C. picta to shed light on whether adult C. picta feed on plants other than the known host plant, Malus spp.

An unexpected diversity of DNA from different non-host plants-woody, herbaceous and different crop plants-was detected in adult C. picta specimens (Table 1 and Figure 1). In a study from Ullman and McLean [55], it was shown that Cacopsylla pyricola feeds on peach, which is a plant that does not serve as a host plant for the nymphal development of this psyllid. Similar to our results, a broad range of non-host plant DNA was detected in adults of following North American psyllids: Aphalara loca (Caldwell 1937) (Hemiptera: Sternorrhyncha: Aphalaridae), Bactericera cockerelli (Šulc 1909) (Hemiptera: Sternorrhyncha: Triozidae), Cacopsylla pyricola (Foerster 1848), Diaphorina citri (Kuwayama 1908) (Hemiptera: Sternorrhyncha: Liviidae) and willow psyllids [44]. In C. pyricola, for example, Salix, Juniperus, Pinus, Humulus and melon (Cucurbitaceae) were identified [44]. These plant taxa have also been determined in C. picta in our study. Furthermore, DNA from Rosaceae $(r b c L a)$, Betulaceae $(r b c L a)$, Fagaceae $(r b c L a)$ and Quercus $(t r n H)$ was found in C. picta. Cacopsylla picta transmits the plant pathogen ' $\mathrm{Ca}$. P. mali', the causative agent of apple proliferation disease. This pathogen was also found in other plant species, e.g., wild, ornamental and cultivated plants belonging to Betulaceae, Fagaceae and Rosaceae: Carpinus betulus [56], Corylus avellana [57], Prunus salicina, Pyrus communis, Pyrus pyrifolia [58], Prunus avium, Quercus robur and Quercus rubra [3]. This coincidence, i.e., that C. picta transmits the phytoplasma during feeding and that the phytoplasma can be found in the above-mentioned plants, supports the assumption that adults of $C$. picta exploit a wide range of feeding plants. However, the role of these plants as reservoir plants in the transmissive cycle of ' $\mathrm{Ca}$. P. mali' is unclear. Generally, every feeding plant of $C$. picta might play a role as a reservoir plant, and thus, our results provide an important starting point to elucidate which plant taxa are worth being considered as potential reservoir plants. However, it remains unknown if acquisition and transmission is feasible when psyllids feed from non-host plants. A pre-requisition that a plant plays a role as a reservoir plant is that the phytoplasma can colonize its phloem and that it can be transmitted to the insect. Since the dwelling time of the insect on its host plant is presumably longer than on its feeding or casual plants, the efficiency of pathogen acquisition from an infected insect host plant is probably higher. Similarly, it can be assumed that the long dwelling time increases the probability that an infected insect transmits the pathogen to its host plant. If a pathogen can colonize the plant but cannot be transmitted to the 
vector insect during feeding, the plant is a dead-end host [12]. The role of feeding plants of adult C. picta in the 'Ca. P. mali' transmission cycle has not been analyzed, yet.

The detection of DNA from a high number of non-host plants in adults of $C$. picta emphasizes that these insects do not stay exclusively on Malus spp. during their dwelling time in the apple orchard. The insects might have been transported to the scrub layer or to plants in the vicinity of the apple orchard passively by wind or rain, or they actively dispersed in the surrounding area, e.g., as a reaction to high population pressure [22,59]. C. picta remigrants are sexually mature and search for mating partners and oviposition sites on Malus spp. [16,60]. Until now, the food plant range of $C$. picta remigrants has been scarcely described in the literature. Forno and colleagues observed that emigrants of C. picta are present in the scrub layer during their presence in the apple orchard [24]. It needs to be considered that emigrants have a different motivation than remigrants to leave their host plant. Emigrants of $C$. melanoneura tend to disperse from the host and Mayer and colleagues observed that they develop this impulse already two days after hatching [61]. Further, Ossiannilsson, as well as Lauterer, described that emigrants of $C$. picta move to annual plants of the genera Brassica, Mentha, Vicia, Phaseolus, Pisum or Avena and later to shelter plants [18,60]. The observations of these authors and the results of our study point out that herbaceous plants, which C. picta has rarely been associated with, also play a certain role for transit and feeding in the life cycle of this insect.

It is known that C. picta overwinters on conifers (Coniferales) $[17,21]$, but it is still under debate if they feed on shelter plants. Gallinger and Gross demonstrated with the use of electronic penetration graphs that Cacopsylla pruni (Scopoli 1763) feeds on conifers under laboratory conditions [62]. The results of our study show, for the first time, that DNA from Picea, Pinus and Cedrus can be detected in C. picta. DNA from Pinaceae was also found in C. pyricola [44]. These findings strengthen the hypothesis that the members of the genus Cacopsylla feed on plants of the Pinaceae family.

Interestingly, Pinaceae DNA was found in remigrants and emigrants in almost equal proportions. It can be assumed that $C$. picta adults also probed or fed on conifers on their way to the apple orchard or in the surrounding vegetation. All emigrants were caught in the Mais orchard, which is located on a mountainside at around $700 \mathrm{~m}$ above sea level. Thus, it is possible that emigrants coming from the lower valleys passed this orchard to reach higher mountain regions, where their coniferous winter shelter plants are located. In one of the emigrant specimens, Vitis DNA was identified, but the nearest vineyard is located about $500 \mathrm{~m}$ from the sampling location. This supports the hypothesis that some of the emigrants arrived from apple orchards in the lower located valley. Furthermore, our data indicate that $C$. picta emigrants already begin to migrate to shelter plants during summer, as it was also observed for $C$. melanoneura $[61,63]$. This suggests that adult $C$. picta feed on different plants during migration.

DNA from Rosaceae was found in almost all analyzed individuals and with the taxonomicallydeeper-reaching $\operatorname{trnH}$ sequencing approach, Malus was identified as the only member of the Rosaceae family present in the analyzed insects (Figures 1 and 2). As expected, most reads could be assigned to Malus, the host on which C. picta feeds and develops (Table 1). The presence of DNA of the known host plant in the phloem-feeding insect indicates that the applied sequencing approach is applicable for the detection of plant DNA in C. picta. No other plant genus was found as abundantly in the insects as Malus. To determine whether a particular psyllid used other plants for feeding or probing purposes, the amount of plant DNA found in the insect might be indicative. The abundance of sequence reads strongly depends on how much plant material the insect ingested and how much time passed since the feeding or probing event [44]. During the digestive process, plant DNA may be partially or completely degraded [64]. The read numbers may provide a rough idea of how much plant DNA was ingested, but a detailed interpretation of the read numbers is not recommended [44]. Based on these limitations and the fact that significant amounts of DNA might be ingested via sources other than the phloem sap (e.g., during cellular penetration), we cannot define whether the identified plants serve as feeding or as casual plants. The two collection methods. i.e., beat tray vs. sticky trap, did not differ regarding the number of sequence reads or the number of different taxa that were detected. This indicates that chemical reagents on the sticky trap and the circumstance that the insect has been probably dead since 
days did not technically hamper DNA extraction and quality. This is in line with the findings described by Cooper and co-authors [43].

We found that the dietary composition of C. picta is influenced by the fauna at the sampling location. Betulaceae DNA was mostly identified in specimens from Bosentino, while Pinaceae DNA was identified in specimens from Mais (Figure 2). Interestingly, Fraxinus DNA was found in about $20 \%$ of the insects from seven different sampling sites. Thus, it is possible that C. picta is particularly attracted to this plant genus.

It is unknown how long ingested plant DNA can be detected in C. picta. In the cell rupture feeding bug Apolygus lucorum (Meyer-Dür 1843) (Hemiptera: Heteroptera: Miridae) [65,66], plant DNA was amplifiable up to $20 \mathrm{~h}$ after the feeding event [67]. In Drosophila suzukii (Matsumura 1931) (Diptera: Brachycera: Drosophilidae), a sponging-feeding insect, plant DNA was detectable for a maximum of

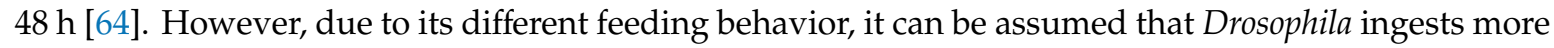
plant DNA than a phloem-feeding insect. In a study with the phloem-feeding $B$. cockerelli, it could be shown in a deep sequencing approach that plant DNA remains detectable for an extended period of at least two weeks after the feeding plant switch [68]. Considering that we found a broad range of plant DNA from different genera in C. picta, it can be assumed that these psyllids also feed on or probe other plants in the surrounding of the host plant, even during their presence in the apple orchard. Psyllids are short-term flyers or they move by jumping; additionally, their movement is undirected and their activity is temperature-dependent [69-72]. Thus, it is unlikely that psyllids can actively overcome large distances, but they can be passively transported over longer distances by wind [21-23]. Considering the mode of translocation and the fact that DNA in a phloem-feeder can be detected for a prolonged time [68], it can be assumed that plants that are far from the sampling site can be detected by our method.

A surface decontamination of the insects was not performed because it cannot be ruled out that DNA destructing agents commonly used for decontamination penetrate the insect's surface and destroy the minimal amounts of plant DNA present in the phloem-feeding insects' intestinal system. On the other hand, a short decontamination time or low concentrations of decontamination solutions do not assure that the actual contaminant is removed. The most uncontrollable source of contamination is pollen, which can be air- or plant-borne. Pollen might firmly stick to the insect's body and, thus, be a source of contamination since it is not easily removed during the preparation steps. Furthermore, whether an insect carries pollen contamination cannot be evaluated by the naked eye. The doubt of detecting contamination-derived amplicons was dispelled because we only found minimal amounts of pollen grains and did not observe any other plant-derived particles on the insect's body (Table A2 and Figure A1). To further reduce the probability that plant DNA derived from surface-attached pollen is amplified, primers were used that target chloroplastic DNA. Pollen contains these organelles only in minor and negligible quantities [73-75]. During the quality processing of the sequence results, sequences with abundances less than 100 reads were not considered. Thus, considering the fact that only minimal amounts of pollen were found on the insects' bodies, in combination with the use of primers that amplify chloroplast loci and the stringent quality control, the probability to generate artifact sequencing results from surface-attached particles was negligible. Beside this, it could be shown in a previous study, which was conducted with psyllids deriving from a colony, that decontamination did not improve the overall sequencing results [43].

In summary, our data show, for the first time, that adult C. picta harbor DNA from many different plant taxa, proving that adult $C$. picta are feeding and probing on several different plant species. We emphasize that our data do not indicate that C. picta reproduces on any other plant but Malus spp., and that it is correctly considered a monophagous psyllid species with regard to the host range of immatures. Furthermore, we found DNA of plants in which ' $\mathrm{C} a$. P. mali' has been detected in previous studies, indicating that these plant taxa might play a role in C. picta-mediated phytoplasma transmission. Thus, our results also provide an important step towards the elucidation of the role of C. picta feeding plants in the phytoplasma transmission cycle. 


\section{Conclusions}

Our data show, for the first time, that adult Cacopsylla picta carry DNA from many different woody and herbaceous plant taxa which do not belong to the host plant of the insect, i.e., Malus spp. These findings show that these insects do not stay exclusively on their host plant during their dwell time in the apple orchard. Interestingly, the results of our study point out that herbaceous plants, which C. picta has rarely been associated with, are also used for transit and feeding. C. picta transmits ' $\mathrm{Ca}$. P. mali', i.e., the causative agent of apple proliferation disease, and the role of these feeding plants as transmissive or dead-end hosts remains elusive. The dietary composition of C. picta seems to be influenced by the fauna at the sampling location. The identification of DNA from the Pinaceae plant family strengthens the hypothesis that members of the genus Cacopsylla feed on conifers during hibernation.

Supplementary Materials: The following are available online at http://www.mdpi.com/2075-4450/11/12/835/s1, Table S1: Number of sequence reads for each C. picta specimen and plant taxa for the $\operatorname{trnH}$ locus. Table S2: Number of sequence reads for each C. picta specimen and plant taxa for the $r b c L a$ locus.

Author Contributions: Conceptualization, D.B. (Dana Barthel) and K.J.; methodology, D.B. (Dana Barthel), J.G. (Jacob Geier), and K.H.; software, J.G. (Jonas Galli), L.B.; validation, D.B. (Dana Barthel), J.G. (Jonas Galli), and L.B.; formal analysis, D.B. (Dana Barthel), K.J., H.S., J.G. (Jonas Galli), J.G.(Jacob Geier), and L.B; data curation, D.B. (Dana Barthel); writing-original draft preparation, D.B. (Dana Barthel) and K.J.; writing-review and editing, D.B. (Dana Barthel), K.J., H.S., D.B. (Daniel Burckhardt), J.G. (Jonas Galli), J.G.(Jacob Geier), L.B., and K.H.; visualization, D.B. (Dana Barthel); supervision, K.J.; project administration, K.J.; funding acquisition, K.J. All authors have read and agreed to the published version of the manuscript.

Funding: The work was performed as part of the project APPLClust and APPLIII within the framework agreement in the field of invasive species in fruit growing and major pathologies (PROT. VZL_BZ 09.05.2018 0002552), which was co-funded by the Autonomous Province of Bozen/Bolzano, Italy and the South Tyrolean Apple Consortium. The authors thank the Department of Innovation, Research and Universities of the Autonomous Province of Bozen/Bolzano for covering the Open Access publication costs. H.S. was funded by the Austrian Science Fund (FWF; project number P31441).

Acknowledgments: We thank Thomas Letschka from Laimburg Research Centre for constructive and fruitful discussions. Stephanie Vossmann from LGC Genomics (Germany) for her support. A special thanks to Evi Mitterrutzner, Cecilia Mittelberger, Bernd Panassiti, Stefanie Fischnaller, Martin Parth and Manuel Messner for insect sampling and Christine Kerschbamer for DNA preparation. We thank Siegfried Tatzreiter and Werner Kofler from the Department of Botany at the Leopold-Franzens-Universität Innsbruck (Austria) for providing the protocol for pollen grain staining. English proof-reading of the manuscript was performed by Amy Kadison.

Conflicts of Interest: The authors declare no conflict of interest. The funders had no role in the design of the study; in the collection, analyses, or interpretation of data; in the writing of the manuscript, or in the decision to publish the results.

\section{Appendix A}

Table A1. Statistical parameters for the total numbers of sequence reads before (raw) and after (clean) quality control for the two loci ( $\operatorname{trnH}$ and $r b c L a)$.

\begin{tabular}{ccccccc}
\hline Locus & Status & Min & Mean & Max & Sd & Total \\
\hline trnH & raw & 22 & 4464 & 71,841 & 9935 & 424,109 \\
trnH & clean & 20 & 4141 & 69,315 & 9577 & 393,442 \\
rbcLa & raw & 7 & 813 & 2754 & 167 & 78,026 \\
rbcLa $a$ & clean & 2 & 144 & 1143 & 167 & 13,780 \\
\hline
\end{tabular}

Table A2. Number of pollen grains detected on C. picta specimens; $n=$ number of pollen grains, nTypes $=$ number of pollen taxa.

\begin{tabular}{cccc}
\hline Sample Name & $\boldsymbol{n}$ & nTypes & Sex \\
\hline C. picta 1 & 1 & 1 & female \\
C. picta 2 & 4 & 4 & female \\
C. picta 3 & 3 & 3 & female \\
C. picta 4 & 3 & 1 & female \\
C. picta 5 & 2 & 2 & female \\
\hline
\end{tabular}




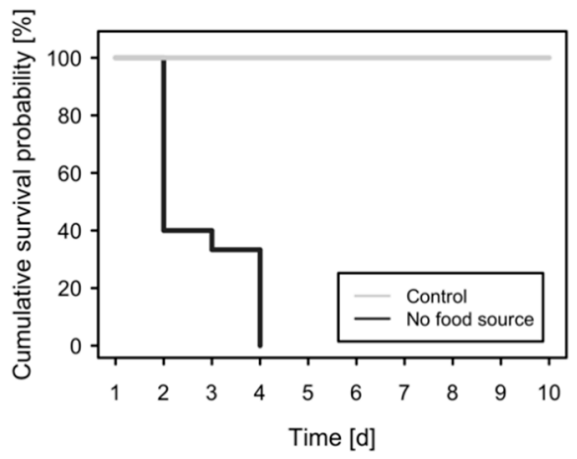

Figure A1. Mortality of reared C. picta emigrants, kept without food and water.

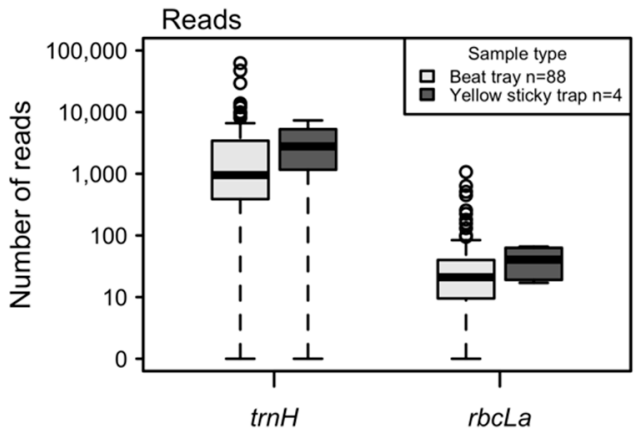

(a)

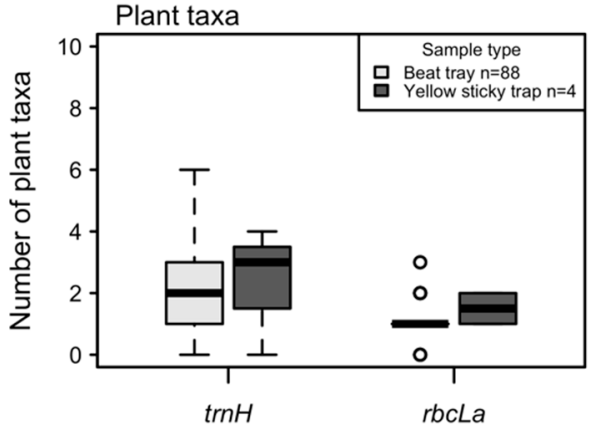

(b)

Figure A2. Comparison of sample type: (a) the numbers of reads displayed on a logarithmic scale according to the sample type and (b) the numbers of plant taxa in specimens according to the sample type.

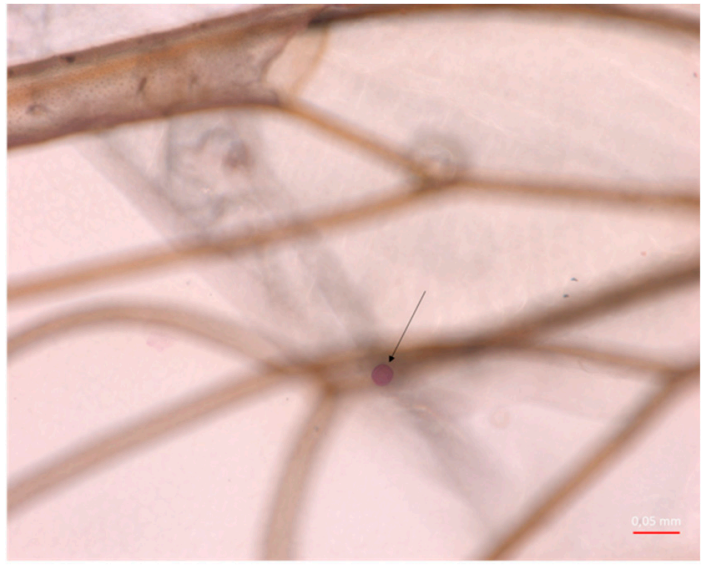

(a)

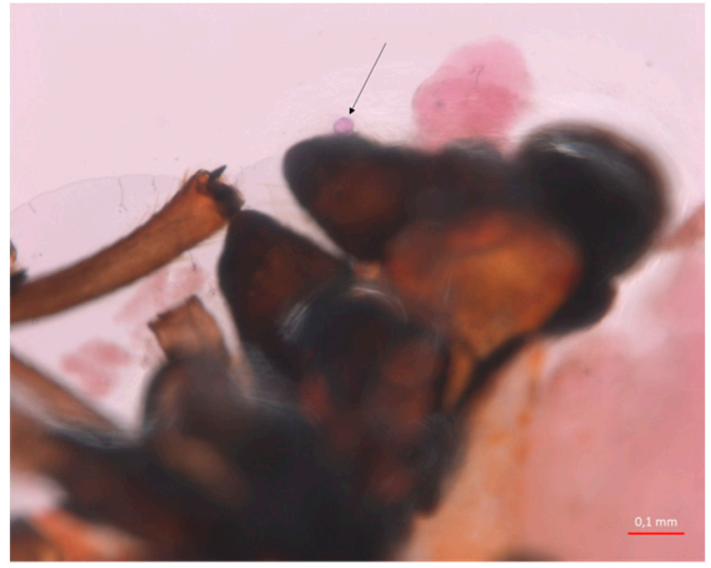

(b)

Figure A3. Detection of pollen grains (indicated with a black arrow) on the body surface of C. picta (a) on a wing; and (b) on genal processes.

\section{References}

1. Seemüller, E.; Schneider, B. 'Candidatus Phytoplasma mali', ‘Candidatus Phytoplasma pyri' and 'Candidatus Phytoplasma prunorum', the causal agents of apple proliferation, pear decline and European stone fruit yellows, respectively. Int. J. Syst. Evol. Microbiol. 2004, 54, 1217-1226. [CrossRef] [PubMed]

2. Seemüller, E. Apple proliferation. In Compendium of apple and pear diseases; Jones, A.L., Aldwinkel, H.S., Eds.; APS Press: St. Paul, MN, USA, 1990; pp. 67-68. 
3. Seemüller, E.; Carraro, L.; Jarausch, W.; Schneider, B. Chapter 14: Apple Proliferation Phytoplasma. In Virus and virus-like diseases of pome and stone fruits; Hadidi, A., Barba, M., Candresse, T., Jelkmann, W., Eds.; APS Press: St. Paul, MN, USA, 2011; pp. 67-73.

4. Strauss, E. Microbiology. Phytoplasma research begins to bloom. Science 2009, 325, 388-390. [CrossRef] [PubMed]

5. Janik, K.; Barthel, D.; Oppedisano, T.; Anfora, G. Apple Proliferation. A Joint Review; Fondazione Edmund Mach, San Michele all'Adige (TN)/Laimburg Research Centre: Ora, Italy, 2020; ISBN 9788878430549.

6. Krczal, G.; Krczal, H.; Kunze, L. Fieberiella florii (Stål), a vector of apple proliferation agent. Acta Hortic. 1988, 235, 99-106. [CrossRef]

7. Frisinghelli, C.; Delaiti, L.; Grando, M.S.; Forti, D.; Vindimian, M.E. Cacopsylla costalis (Flor 1861), as a vector of apple proliferation in Trentino. J. Phytopathol. 2000, 148, 425-431. [CrossRef]

8. Jarausch, B.; Schwind, N.; Jarausch, W.; Krczal, G.; Dickler, E.; Seemüller, E. First Report of Cacopsylla picta as a Vector of Apple Proliferation Phytoplasma in Germany. Plant Dis. 2003, 87, 101. [CrossRef] [PubMed]

9. Tedeschi, R.; Alma, A. Transmission of apple proliferation phytoplasma by Cacopsylla melanoneura (Homoptera: Psyllidae). J. Econ. Entomol. 2004, 97, 8-13. [CrossRef] [PubMed]

10. Tedeschi, R.; Alma, A. Fieberiella florii (Homoptera: Auchenorrhyncha) as a Vector of 'Candidatus Phytoplasma mali'. Plant Dis. 2006, 90, 284-290. [CrossRef]

11. Oppedisano, T.; Panassiti, B.; Pedrazzoli, F.; Mittelberger, C.; Bianchedi, P.L.; Angeli, G.; de Cristofaro, A.; Janik, K.; Anfora, G.; Ioriatti, C. Importance of psyllids' life stage in the epidemiology of apple proliferation phytoplasma. J Pest Sci 2019, 57, 135. [CrossRef]

12. Weintraub, P.G.; Beanland, L. Insect vectors of phytoplasmas. Annu. Rev. Entomol. 2006, 51, 91-111. [CrossRef]

13. Mittelberger, C.; Obkircher, L.; Oettl, S.; Oppedisano, T.; Pedrazzoli, F.; Panassiti, B.; Kerschbamer, C.; Anfora, G.; Janik, K. The insect vector Cacopsylla picta vertically transmits the bacterium 'Candidatus Phytoplasma mali' to its progeny. Plant Pathol. 2017, 66, 1015-1021. [CrossRef]

14. Jarausch, B.; Fuchs, A.; Schwind, N.; Krczal, G.; Jarausch, W. Cacopsylla picta as most important vector for 'Candidatus Phytoplasma mali' in Germany and neighbouring regions. Bull. Insectology 2007, 60, 189-190.

15. Jarausch, B.; Burckhardt, D.; Lauterer, P.; Jarausch, W. Psyllids (Hemiptera, Psylloidea) captured in commercial apple and stone fruit orchards in southwest Germany, eastern France and northwest Switzerland. Mitt. Schweiz. Entomol. Ges. 2009, 82, 205-215.

16. Jarausch, B.; Tedeschi, R.; Sauvion, N.; Gross, J.; Jarausch, W. Psyllid Vectors. In Phytoplasmas: Plant Pathogenic Bacteria—II; Bertaccini, A., Weintraub, P.G., Rao, G.P., Mori, N., Eds.; Springer Singapore: Singapore, 2019; pp. 53-78.

17. Reuter, O.M. Charakteristik und Entwicklungsgeschichte der Hemipteren-Fauna (Heteroptera, Auchenorrhynchia und Psyllidae) der palaearktischen Coniferen. Acta Soc. Sci. Fenn. 1909, 36, 1-129.

18. Ossiannilsson, F. The Psylloidea (Homoptera) of Fennoscandia and Denmark; Brill: Leiden, The Netherlands, 1992; ISBN 90-04-09610-8.

19. Mattedi, L.; Forno, F.; Cainelli, C.; Grando, M.S.; Jarausch, W. Research on Candidatus Phytoplasma mali transmission by insect vectors in Trentino. Acta Hortic. 2008, 369-374. [CrossRef]

20. Fischnaller, S.; Parth, M.; Messner, M.; Stocker, R.; Kerschbamer, C.; Reyes-Dominguez, Y.; Janik, K. Occurrence of different Cacopsylla species in apple orchards in South Tyrol (Italy) and detection of apple proliferation phytoplasma in Cacopsylla melanoneura and Cacopsylla picta (Hemiptera: Psylloidea). Cicadina 2017, 17, 37-51.

21. Čermák, V.; Lauterer, P. Overwintering of psyllids in South Moravia (Czech Republic) with respect to the vectors of the apple proliferation cluster phytoplasmas. Bull. Insectol. 2008, 61, 147-148.

22. Burckhardt, D.; Ouvrard, D.; Queiroz, D.; Percy, D. Psyllid Host-Plants (Hemiptera: Psylloidea): Resolving a Semantic Problem. Fla. Entomol. 2014, 97, 242-246. [CrossRef]

23. Thébaud, G.; Yvon, M.; Alary, R.; Sauvion, N.; Labonne, G. Efficient transmission of ‘Candidatus phytoplasma prunorum' Is delayed by eight months due to a long latency in its host-alternating vector. Phytopathology 2009, 99, 265-273. [CrossRef]

24. Forno, F.; Mattedi, L.; Vindimian, M.E.; Branz, A.; Forti, D.; Schgraffer, M. Tre anni di osservazioni sulle psille del melo. Terra Trentina 2002, 3, 25-29. 
25. Zimmermann, M.H.; Ziegler, H. Transport in plants I: Phloem transport. Encyclopedia of Plant Physiology; Springer: New York, NY, USA, 1975; Volume 1.

26. Van Bel, A.J.E. The phloem, a miracle of ingenuity. Plant Cell Environ. 2003, 26, 125-149. [CrossRef]

27. Civolani, S.; Leis, M.; Grandi, G.; Garzo, E.; Pasqualini, E.; Musacchi, S.; Chicca, M.; Castaldelli, G.; Rossi, R.; Tjallingii, W.F. Stylet penetration of Cacopsylla pyri; an electrical penetration graph (EPG) study. J. Insect Physiol. 2011, 57, 1407-1419. [CrossRef] [PubMed]

28. Butler, C.D.; Walker, G.P.; Trumble, J.T. Feeding disruption of potato psyllid, Bactericera cockerelli, by imidacloprid as measured by electrical penetration graphs. Entomologia Experimentalis et Applicata 2012, 142, 247-257. [CrossRef]

29. Liang, X.; Zhang, C.; Li, Z.; Xu, L.; Dai, W. Fine structure and sensory apparatus of the mouthparts of the pear psyllid, Cacopsylla chinensis (Yang et Li) (Hemiptera: Psyllidae). Arthropod Struct. Dev. 2013, 42, 495-506. [CrossRef] [PubMed]

30. George, J.; Ammar, E.-D.; Hall, D.G.; Lapointe, S.L.; Ghanim, M. Sclerenchymatous ring as a barrier to phloem feeding by Asian citrus psyllid: Evidence from electrical penetration graph and visualization of stylet pathways. PLoS ONE 2017, 12, e0173520. [CrossRef] [PubMed]

31. Kehr, J. Phloem sap proteins: Their identities and potential roles in the interaction between plants and phloem-feeding insects. J. Exp. Bot. 2006, 57, 767-774. [CrossRef]

32. Blackman, L.M.; Overall, R.L. Immunolocalisation of the cytoskeleton to plasmodesmata of Chara corallina. Plant J. 1998, 14, 733-741. [CrossRef]

33. Sjolund, R.D. The Phloem Sieve Element: A River Runs through It. Plant Cell 1997, 1137-1146. [CrossRef]

34. Miles, P.W. Aphid saliva. Biol. Rev. 1999, 74, 41-85. [CrossRef]

35. Zabotin, A.I.; Barysheva, T.S.; Trofimova, O.I.; Lozovaya, V.V.; Widholm, J. Regulation of Callose Metabolism in Higher Plant Cells in vitro. Russ. J. Plant Physiol. 2002, 49, 792-798. [CrossRef]

36. Richter, S.; Müssig, J.; Gierlinger, N. Functional plant cell wall design revealed by the Raman imaging approach. Planta 2011, 233, 763-772. [CrossRef]

37. Ullman, D.E.; McLean, D.L. Anterior alimentary canal of the pear Psylla, Psylla pyricola foerster (Homoptera, Psyllidae). J. Morphol. 1986, 189, 89-98. [CrossRef] [PubMed]

38. Horton, D.R.; Krysan, J.L. Host Acceptance Behavior of Pear Psylla (Homoptera: Psyllidae) Affected by Plant Species, Host Deprivation, Habituation, and Eggload. Ann. Entomol. Soc. Am. 1991, 84, 612-627. [CrossRef]

39. García-Robledo, C.; Erickson, D.L.; Staines, C.L.; Erwin, T.L.; Kress, W.J. Tropical plant-herbivore networks: Reconstructing species interactions using DNA barcodes. PLoS ONE 2013, 8, e52967. [CrossRef] [PubMed]

40. Díaz Villanueva, V.; Albariño, R. Algal ingestion and digestion by two ephemeropteran larvae from a Patagonian Andean stream. In Research Update on Ephemeroptera E Plecoptera; Gaino, E., Ed.; Università di Perugia: Perugia, Italy, 2003; pp. 468-475.

41. Hugo, R.L.E.; Merritt, D.J.; Wild, C.H. Gut Content Analysis to Distinguish Between Seed Feeding and Mycophagy of a Biphyllid Beetle Larva Found on Acacia melanoxylon. Biocontrol Sci. Technol. 2010, 13, 355-360. [CrossRef]

42. Kajtoch, Ł. A DNA metabarcoding study of a polyphagous beetle dietary diversity: The utility of barcodes and sequencing techniques. Folia Biol. 2014, 62, 223-234. [CrossRef] [PubMed]

43. Cooper, W.R.; Horton, D.R.; Unruh, T.R.; Garczynski, S.F. Gut Content Analysis of a Phloem-Feeding Insect, Bactericera cockerelli (Hemiptera: Triozidae). Environ. Entomol. 2016, 45, 938-944. [CrossRef]

44. Cooper, W.R.; Horton, D.R.; Wildung, M.R.; Jensen, A.S.; Thinakaran, J.; Rendon, D.; Nottingham, L.B.; Beers, E.H.; Wohleb, C.H.; Hall, D.G.; et al. Host and Non-host 'Whistle Stops' for Psyllids: Molecular Gut Content Analysis by High-Throughput Sequencing Reveals Landscape-Level Movements of Psylloidea (Hemiptera). Environ. Entomol. 2019, 48, 603-613. [CrossRef]

45. De Schepper, V.; de Swaef, T.; Bauweraerts, I.; Steppe, K. Phloem transport: A review of mechanisms and controls. J. Exp. Bot. 2013, 64, 4839-4850. [CrossRef]

46. Paramonova, N.V.; Krasavina, M.S.; Sokolova, S.V. Ultrastructure of Chloroplasts in Phloem Companion Cells and Mesophyll Cells as Related to the Stimulation of Sink Activity by Cytokinins. Russ. J. Plant Physiol. 2002, 49, 187-195. [CrossRef]

47. Oettl, S.; Schlink, K. Molecular Identification of Two Vector Species, Cacopsylla melanoneura and Cacopsylla picta (Hemiptera: Psyllidae), of Apple Proliferation Disease and Further Common Psyllids of Northern Italy. J. Econ. Entomol. 2015, 108, 2174-2183. [CrossRef] [PubMed] 
48. Sang, T.; Crawford, D.J.; Stuessy, T.F. Chloroplast DNA phylogeny, reticulate evolution, and biogeography of Paeonia (Paeoniaceae). Am. J. Bot. 1997, 84, 1120-1136. [CrossRef] [PubMed]

49. Tate, J.A.; Simpson, B.B. Paraphyly of Tarasa (Malvaceae) and diverse origins of the polyploid species. Syst. Bot. 2003, 28, 723-737. [CrossRef]

50. Kress, W.J.; Erickson, D.L. A two-locus global DNA barcode for land plants: The coding rbcL gene complements the non-coding trnH-psbA spacer region. PLoS ONE 2007, 2, e508. [CrossRef] [PubMed]

51. Kress, W.J.; Erickson, D.L.; Jones, F.A.; Swenson, N.G.; Perez, R.; Sanjur, O.; Bermingham, E. Plant DNA barcodes and a community phylogeny of a tropical forest dynamics plot in Panama. Proc. Natl. Acad. Sci. USA 2009, 106, 18621-18626. [CrossRef] [PubMed]

52. Callahan, B.J.; McMurdie, P.J.; Rosen, M.J.; Han, A.W.; Johnson, A.J.A.; Holmes, S.P. DADA2: High-resolution sample inference from Illumina amplicon data. Nat. Methods 2016, 13, 581-583. [CrossRef] [PubMed]

53. Wilhalm, T.; Niklfeld, H.; Gutermann, W. Katalog der Gefäßpflanzen Südtirols; Folio Verlag: Wien, Austria, 2006.

54. Autonome Provinz Bozen-Südtirol. Bäume und Sträucher. Available online: http://www.provinz.bz.it/ land-forstwirtschaft/wald-holz-almen/forstgaerten/zur-verfuegung-stehende-pflanzen.asp (accessed on 7 October 2020).

55. Ullman, D.E.; McLean, D.L. Feeding Behavior of the Winter-Form Pear Psylla, Psylla pyricola (Homoptera: Psyllidae), on Reproductive and Transitory Host Plants. Environ. Entomol. 1988, 17, 675-678. [CrossRef]

56. Seemüller, E. Apple proliferation: Etiology, epidemiology and detection. In Atti Giornate Fitopatologiche 2002; Giornate Fitopatologiche, Trento, Baselga di Piné, Italy, 7.-11.04.2002; Brunelli, A., Canova, A., Eds.; CLUEB: Bologna, Italy, 2002; pp. 3-6.

57. Marcone, C.; Ragozzino, A.; Seemüller, E. Association of phytoplasmas with the decline of European hazel in southern Italy. Plant Pathol. 1996, 45, 857-863. [CrossRef]

58. Lee, I.M.; Bertaccini, A.; Vibio, M.; Gundersen, D.E. Detection of multiple phytoplasmas in perennial fruit trees with decline symptoms in Italy. Phytopathology 1995, 85, 728-735. [CrossRef]

59. Horton, D.R.; Burts, E.C.; Unruh, T.R.; Krysan, J.L.; Coop, L.B.; Croft, B.A. Intraorchard changes in distribution of winterform pear psylla (Homoptera: Psyllidae) associated with leaf fall in pear. Ann. Entomol. Soc. Am. 1993, 86, 599-608. [CrossRef]

60. Lauterer, P. Results of the investigation on Hemiptera in Moravia, made by the Moravian museum (Psylloidea 2). Acta Mus. Morav. Sci. Biol. 1999, 84, 71-151.

61. Mayer, C.J.; Gross, J. Different host plant odours influence migration behaviour of Cacopsylla melanoneura (Forster), an insect vector of the apple proliferation phytoplasma. IOBC/WPRS Bull. 2007, 30, 177-184.

62. Gallinger, J.; Gross, J. Unraveling the Host Plant Alternation of Cacopsylla pruni-Adults but Not Nymphs Can Survive on Conifers Due to Phloem/Xylem Composition. Front. Plant Sci. 2018, 9, 484. [CrossRef] [PubMed]

63. Mayer, C.J.; Jarausch, B.; Jarausch, W.; Jelkmann, W.; Vilcinskas, A.; Gross, J. Cacopsylla melanoneura has no relevance as vector of apple proliferation in Germany. Phytopathology 2009, 99, 729-738. [CrossRef] [PubMed]

64. Briem, F.; Zeisler, C.; Guenay, Y.; Staudacher, K.; Vogt, H.; Traugott, M. Identifying plant DNA in the sponging-feeding insect pest Drosophila suzukii. J Pest Sci 2018, 91, 985-994. [CrossRef]

65. Backus, E.A.; Serrano, M.S.; Ranger, C.M. Mechanisms of hopperburn: An overview of insect taxonomy, behavior, and physiology. Annu. Rev. Entomol. 2005, 50, 125-151. [CrossRef]

66. Li, W.; Wyckhuys, K.A.G.; Wu, K. Does feeding behavior of a zoophytophagous mirid differ between host plant and insect prey items? Arthropod-Plant Interact. 2016, 10, 79-86. [CrossRef]

67. Wang, Q.; Bao, W.-F.; Yang, F.; Xu, B.; Yang, Y.-Z. The specific host plant DNA detection suggests a potential migration of Apolygus lucorum from cotton to mungbean fields. PLoS ONE 2017, 12, e0177789. [CrossRef]

68. Cooper, W.R.; Horton, D.R. Molecular Gut Content Analysis to Pinpoint Where Psylla Overwinter. 2017. Available online: https://reefruitresearch.org/report/molecular-gut-content-analysis-to-pinpoint-wherepsylla-overwinter/ (accessed on 20 November 2020).

69. Davis, M.A. Why are most insects short fliers? Evol. Theory 1980, 5, 103-111.

70. Horton, D.R.; Lewis, T.M. Tethered flight activity of pear psylla, Cacopsylla pyricola: Seasonal, host, and morphotypic effects. Entomol. Exp. Appl. 1996, 78, 39-49. [CrossRef]

71. Burrows, M. Jumping mechanisms in jumping plant lice (Hemiptera, Sternorrhyncha, Psyllidae). J. Exp. Biol. 2012, 215, 3612-3621. [CrossRef] 
72. Barthel, D.; Kerschbamer, C.; Panassiti, B.; Malenovský, I.; Janik, K. Effect of Daytime and Tree Canopy Height on Sampling of Cacopsylla melanoneura, a ‘Candidatus Phytoplasma mali' Vector. Plants 2020, 9, 1168. [CrossRef] [PubMed]

73. Willerslev, E.; Hansen, A.J.; Binladen, J.; Brand, T.B.; Gilbert, M.T.P.; Shapiro, B.; Bunce, M.; Wiuf, C.; Gilichinsky, D.A.; Cooper, A. Diverse plant and animal genetic records from Holocene and Pleistocene sediments. Science 2003, 300, 791-795. [CrossRef] [PubMed]

74. Sakamoto, W.; Miyagishima, S.-Y.; Jarvis, P. Chloroplast biogenesis: Control of plastid development, protein import, division and inheritance. Arabidopsis Book 2008, 6, e0110. [CrossRef] [PubMed]

75. Matsushima, R.; Tang, L.Y.; Zhang, L.; Yamada, H.; Twell, D.; Sakamoto, W. A conserved, Mg²+-dependent exonuclease degrades organelle DNA during Arabidopsis pollen development. Plant Cell 2011, 23, 1608-1624. [CrossRef] [PubMed]

Publisher's Note: MDPI stays neutral with regard to jurisdictional claims in published maps and institutional affiliations.

(C) 2020 by the authors. Licensee MDPI, Basel, Switzerland. This article is an open access article distributed under the terms and conditions of the Creative Commons Attribution (CC BY) license (http://creativecommons.org/licenses/by/4.0/). 